\title{
The Role of Project Finance in Contemporary Financing:
}

\section{"Theoretical Perspective"}

\author{
John K.M.Mawutor ${ }^{1} \&$ Obeng Kwadwo ${ }^{1}$ \\ ${ }^{1}$ University of Professional Studies, Accra, Ghana \\ Correspondence: Dr. John K.M.Mawutor, University of Professional Studies, Accra, Ghana. P.O.Box 149, Legon. \\ Accra, Ghana.Tel: 233-24-328-7242. E-mail: john.mensah@upsamail.due.gh / kwaku2mensah@gmail.com
}

Received: October 13, 2014

Accepted: November 5, 2014

Online Published: November 11, 2014

doi:10.5430/afr.v3n4p181

URL: http://dx.doi.org/10.5430/afr.v3n4p181

\begin{abstract}
Funding projects through Project Finance arrangements in contemporary Economic and Corporate and economic governance has become the catalyst for developing capital intensive projects in most Organizations and Nations. Unlike corporate finance, project finance is a non-recourse debt that is financed through cash generated from the project. This paper examined the increasing reliance on project finance in recent times by assessing its merits over traditional corporate financing and described the operation of a typical Project Finance Scheme. Using a Descriptive Analysis, the theoretical underpinnings of this subject matter were assessed. Historical data on project costs using project financing were evaluated. The study revealed that the successful completion of most capital intensive projects were initiated and completed through project finance schemes. However, the ultimate key to projects finance is the accurate estimation and evaluation of project viability.
\end{abstract}

Keywords: Project finance, Capital intensive, Non-recourse, Historical, Schemes

\section{Introduction}

\subsection{Background of Study}

The 21ST Century has witnessed substantial surge in public-private-partnership (PPP) to develop infrastructure in most developing and developed countries (Mawutor, 2014; IFC, 2011). Whereas corporate entities aim at diversifying their capital structure, government in most countries explore project finance to develop their basic infrastructural needs. As at December 2010, funding of project through project finance had increased to US\$167 billion (KPMG, 2010). In 2011, Cameroun explored project financing structuring to finance a 216 megawatt natural gas-fire power plant at the cost of $£ 198$ million over a 12 year period (IFC, 2011). Through the coordinated effort of the International Finance Corporation (IFC), the Chinese, Argentine, Nigerian and other countries used project financing to develop their respective infrastructural needs. In 1997, the IFC facilitated the arrangement of \$26 million in syndicated loans to finance the plantation of Timber products in China (Thompson, 2010). The same arrangement was made for Mozambique in 1998 to raise 1.3 billion dollars to establish Aluminum smelter project. In essence, the growing global demand for infrastructure, clearly indicate that project finance remains one of the main source of funding capital incentive project (Esty, 2004).

\subsection{Main Objective}

In view of the significant roles of project finance towards the development of most entities and economies, this paper seeks to assess the increasing reliance by government and corporate firms to raise funds for investments by reviewing the attributes of Projects Finance, its merits over the traditional corporate finance, its shortcomings and description of typical project finance transaction.

\subsection{Overview of Project Finance}

Unlike the traditional loan arrangements, project finance is a financial structure which facilitate the arrangements for project but the repayment of such loans are exclusively defrayed from the cash flows generated from the operations of the project and are specifically used in financing large-scale projects in the areas of oil, energy, petrochemicals, road and railway infrastructure, electricity and water supply et al (Fight, 2005). According to Esty and Sesial (2011), typical project finance structure is an arrangement that involves the establishment of an independent project entity financed with a non-recourse debt to finance a single-purpose capital intensive project. The unique feature of project 
finance is its non-recourse to financing (Hoffman, 2001). Non-recourse finance is an arrangement that limits lenders restitution to the project's collateral but not the other properties of the lenders (Esty, 2006). In case of a default, the non-recourse borrower(s) are not personally held liable for the default. Apart from this unique non-recourse feature, Project Finance structures have bulk of it's arrangements in tangible assets where all of the projects are pledged to the lenders (Yescombe, 2001; Esty, 2006; Fight, 2006). In view of this, project finance arrangements are usually used in long term investments ranging between 5 -20 years (Fight, 2006). Typical project finance evolves through the construction and operational stages where the cash flows generated from the projects are used to offset the debts. According to Fight (2006), the primary parties involved in the project finance are the project company with shareholders, lender, grantor (usually government), contractor, operator, off-take purchaser and input suppliers. Their respective obligations and relationships are provided in the project agreement (Yescombe, 2002).In recent times, the high demand for basic social infrastructural amenities especially in developing countries has precipitated the reliance on the use of project finance (Graham,2004). In fact, projects finance is a structure that equitably distributes projects risks among the various stakeholders (Ghersi \& Sabal, 2002). According to Fight (2006) the high cost of constructing such structures also account for the increasing reliance on project finance to fund such investments. Beside these facts, multinational companies in emerging countries use project finance to reduce their exposure by transferring their risks to other stakeholders (Ghersi \& Sabel, 2002). In cases where the government is the sponsor, the longest established method used is BOT (Build, Operate and Transfer). Under BOT, the contractors and lender constructs the project after which they operates and eventually transfers ownership to the sponsor/government/company (Fight, 2004). The period between operating and transfer of ownership to the sponsor enables the project company to recoup the initial investment (Sabramanian et al, 2007). BOT might take two forms, thus BLT (Build, Lease and Transfer) and BOO (Build, Own and Operate). With BLT, the arrangement entitles the sponsor to lease the project from the contractor for a given period of time after which the sponsor takes full and final possession of the project after the expiration of the lease agreement (Hoffman, 2001). Unlike BLT, BOO empowers the contractor to build, operate and own the assets which will never be returned to the sponsor.

\section{Typical Project finance Transaction}

In view of the increasing reliance on project finance to construct capital intensive project, transaction under project finance are characterized with numerous parties with distinct obligation (Fight, 2006). A well-structured project finance arrangement is stratified into contractual groups. Its arrangements starts with the creation of an independent special purpose vehicle (SPV) Company as a consortium to enter into contractual agreement with a number of players' expedient to the completion and operation of the project (Esty, 2006). The other player with whom the SPV works to complete the project comprises of sponsors, government institutions, clients and financiers, suppliers, contractors (Fight, 2006). The sponsors are the project planners, contactors, suppliers, operators responsible to initiate, develop, complete and actively participate in the management of the project (Esty, 2006) whereas the other operating concerns such as clients are the institutions/individuals that acquire the product and/or services produced and rendered by the project (Ghersi \& Sabal, 2012). In most cases, the government institutions serve as the clients and sponsors concurrently (fight, 2006). Other major groups in the structure are the financiers. These groups comprises of shareholders, banks, export credit agencies, equipment manufacturers, insurers and fund managers (Fight, 2006). The financiers are the parties that provide funds to finance the project and share in the risk of the project by negotiating with all the other parties (Hoffman, 2001). Shareholders in a project finance structure are the risk capital firms and mutual funds participants and issue subordinated debts on the capital (Ghersi \& Sabal, 2012). Banks on the other hand acts as financial intermediaries to raise funds for the project. Apart from their intermediary role, they also take senior debt. Commercial banks, and multilateral institutes such as the CAF, IFC, IMF, play such eminent roles in project finance thereby making them the real participating financiers in developed and emerging markets (Taylor, 2003). Other parties such as export credit agencies, equipment and manufactures and insurers are financial institution that provide guarantee, equipment and risk to the projects lenders (Fight, 2006).

In a nutshell, typical project finance starts with the creation of an independent special purpose Vehicle (SPV) Company. This SPV Company is established as a legal entity to develop and operate the project and comprises of a consortium of sponsors such as contractors, suppliers, investors who negotiate with the other parties such as financiers and government institutions to build and complete the project (Esty, 2006). The project could either be contracted as BOT, BLT or BOO (Fight, 2006; Subramanian et al, 2007).

It is worth mentioning that, the persistent increase in the application of project finance to fund capital intensive projects clearly corroborate the evidential merit of project finance over corporate finance, unlike corporate finance, project finance is used to provide funds for standalone-projects whereas funds sourced under corporate finance are used for the general projects of an entire entity or economy (Estey, 2006). For instance, finance duration under 
corporate finance varies whereas project financed under project finances have long duration thereby covering the entire lifespan of the project in some cases (Ghersi \& Sabal, 2012). In view of these differences, project finance has some specific merits over corporate finance. In project finance schemes, the lenders' recourse to the sponsor is eliminated, apparently; the debts are recouped from the cash flows generated from the operation of the project (Esty, 2004). It also allows off-balance sheet treatment of debt financing where debts held by shareholders are not consolidated into their balance sheet (Fight, 2006). Considering the single purpose attribute of project finance, evaluation of project viability by lenders is simplified. The high agency cost-associated with corporate finance is reduced under corporate finance because the contractual arrangement under project finance permits little margin for independence by the parties (Ghersi \& Sabal, 2012).

\section{Relevant Documents}

Preliminary to contractual agreement under project finance schemes are provisions outlined in information memorandum, analysis of project cash flows and the approval of credit risk (Mawutor, 2014). Given the complex nature of project finance, it is imperative to outline the responsibilities and obligation of the various parties in pursuance of their interest in the scheme. Apparently, thorough evaluation of projects to ensure their success is usually provided for in the memorandum of information. To critically assess the relevance of providing funds to complete a project and generate cash flow to pay off the debts the relevance of information memorandum, cash flow analysis, credit risk appraisal and debt servicing tools in project evaluation is expedient (Mawutor, 2014).

\subsection{Information Memorandum}

One of the principal finance documents in project finance arrangement is the information memorandum (Fight, 2006). In view of the syndicated nature of debts to finance the projects company under project finance, information memorandum outlines details and requirements of all the participants in the project (Walker, 2005). It is a legal document that specifies the objectives, exposures and conditions of investments associated with the project (Ayano, 2010). According to Graham (2005), preliminary information memorandum is a document that contains management's estimation of the projects expenditure revenue term sheet, and other relevant information in relation to the project. In addition, information memorandum provide specific project information such as general description, project company \& sponsors, project participants, technical information, economic information, contacts, project schedules, government's commitment, the market, the independent engineer, access to raw materials, project's profitability, environmental legislation and foreign exchange risk (Fight,2005). The main purpose of this document is to make the project attractive to prospective lenders and investors (Yescombe, 2002).

\section{Financial and Risk Analysis}

\subsection{Cash flow analysis}

Relevant to determine the project and viability of the project is the analysis of cash flows. Cash flow analysis entails the assessment of project cash inflows and outflows from the project. It generally considers how cash could be generated and expanded by showing recurring and capital expenditure of the project. Cash flow analysis involves the analyses of changes in cash and cash equivalents during a period whereby the cash and cash equivalents comprise cash on hand and demand deposits, together with short-term, highly liquid investments that are readily convertible to a known amount of cash and that are subject to an insignificant risk of changes in value (IAS 7, 2009). To examine an entities' cash flow statement, it is imperative to decompose the cash flow into operating activities, investing activities and financing activities. Operating activities - These are revenue generating activities of the company, which normally includes cash receipts from sale of goods and services, cash payments to suppliers for goods and services and disposal gains and losses of fixed assets. Investing activities - These are activities that involve the acquisition and selling of fixed assets (long termed assets like land, building or plant), cash receipts from the disposal of fixed assets and cash payments to acquire fixed assets. Financing activities - These are activities, which change or impact the size and the composition of owners' capital. They include cash proceeds from issuing shares, or debt and payment of dividends. Cash flow analysis aids lenders and prospective lenders to ascertain the changes in cash and gives insight to the company's operating, investing and financial activities. Similarly, cash flow analysis will unveil the company's ability to generate cash to meet its short-term obligations, thereby assessing if company's liquidity and solvency position is sound.

\subsection{Financial Analysis}

A thorough evaluation of the financial statement presented by the borrower is deemed expedient to determine the financial viability of the project. Financial analysis involves the examination of a company's financial statement to determine their profitability, liquidity, solvency and investment capacity of the company in question (Drury, 2009). 
The form of analysis could be undertaken through the employment of ratio analysis, analysis of value added statement, corporate failure prediction techniques, profitability index, common size statements and cash flow analysis (Attulik, 2008). The most widely tool employed in the analysis of financial statement is ratio analysis. It is a technique used by individuals, lenders and investors to conduct a quantitative analysis of information in a company's financial statements. Ratios are calculated from current year numbers and are then compared to previous years, other companies, the industry, or even the economy to judge the performance of the company. Ratio analysis is predominately used by proponents of fundamental analysis. Financial ratios can be divided into liquidity ratios, debts ratio, profitability ratios and coverage ratios (Fight, 2005).

Liquidity ratios measures the capability of companies to meet their immediate obligations thus their short-term liabilities (Wood, 2008). Consequently, a company that is able to settle its liabilities within a finance period is regarded as "highly liquid" and vice-versa. In project finance, a lender will be assured of frequent receipt of interest within a financial period from a highly liquid company. One of the main liquidity ratio used in testing the liquidity of companies is the current ratio. Current ratio measures the number of times a company uses its current assets to settle their current liabilities in the short-run (Wood, 2009). The other forms of liquidity ratios are quick ratios, cash ratios, working capital etc. The current ratio is depicted as: (Current Assets )/(Current Liabilities)

Another area of performance where financial ratios are useful the appraisal of firms' profitability through the use of financial ratios. These ratios measure the companies' ability to efficiently use its resources to maximize returns. It shows the returns available to investors within a financial period (Attulik, 2008). The tools used in profitability ratio analysis are return on capital employed, asset turnover ratios, efficiency ratios, expense to sales ratios, gross profit margins; net profit margins (Jennings, 2001).

Debts ratios are used to measure the indebtedness of a company and several ratios may be used ranging from Debt/Equity ratios, interest cover, gearing ratios (Fight, 2005). The debt to net worth is measured by simply dividing the total debt of the firm with the net worth. Coverage ratio also measures the ability of the company to generate cash flow in excess of its commitments (Fight, 2005). It's imperative to note that credit agencies make extensive use of these ratios.

\subsection{Credit Risk Appraisal}

Before committing and extending credit to project sponsors, lenders conduct series of reviews on the credit worthiness of the borrowers. Credit risk appraisal seeks to ascertain the risks associated with the extension of the credit facility and is generally carried out by the financial institutions which are involved in providing financial funding to its customers (Mawutor, 2014; Marfo, 2003). Credit risk is a risk related to non-repayment of the credit obtained by the customer of a bank. Thus it is necessary to appraise the credibility of the customer in order to mitigate the credit risk therefore, a proper evaluation of the customer is performed which measures the financial conditions and the ability of the customer to repay the loan in future. Consideration for credit analysis varies from institution to institution; however, the general fundamentals are what almost every bank applies to the credit extension (Fight, 2005). The consideration is given at the pre-construction stage which lays emphasis on the experience and the reputation of the project sponsor; engineering and design and construction whereas the post-construction deals with operations and management; experience and resources of the operator; price and supplies of raw materials; value of project assets as collateral (Fight, 2005)

\subsection{Debt Servicing}

Regardless of the revelations by coverage ratios, projects are subject to several financial threats over and above the ability of the project to generate stable and sufficient levels of cash flows especially during the servicing of the debts. In servicing debts, negative impacts can arise despite the effective review of a project's liquidity position. Among these negative impacts are foreign exchange risk, inflation risk, liquidity risk, tax rates, energy costs etc. It is imperative to note that most of these risks can be mitigated by hedging facilities such as forward sales, futures and options contracts, but this will also increase the overall cost funding (Fight, 2005).

\section{Conclusion and Limitations}

\subsection{Limitations of Project Finance}

In spite of the increasing reliance on project finance in developing and creating capital intensives projects in developed and emerging economies, this form of financing projects is characterized with very complex structure (Esty, 2006; Fight, 2006), coupled with very high cost of finance, strict covenants imposed by the various parties and under some processes to be followed in sourcing funds for the project. 


\subsection{Conclusion}

Evidentially, the numerous projects constructed under project finance clearly shows that large and capital intensive projects are susceptible to be successfully financed through project finance. The ultimate key to projects finance is the accurate estimation and evaluation of a project's cash flows viability coupled with the distribution of risk exposure among members of the consortium. In spite of its complex nature and high cost of finance, project finance will continue to exist as a strategic scheme for funding long-term capital intensive project. The risk associated with the structure should also be studied by practitioners and academicians to aim at reducing the risk exposures to the various parties.

\section{References}

Attuilik Willam A. (2008). Corporate Reporting Strategy. Asempa Publishing. 1st Edition. Accra Ghana.

Drury Collin (2009). Management and Cost Accounting. 6th Edition.Thompson Learning Publishers.

E.R. Yebscombe (2002). Principles of Project Finance. Academic Press USA.

Esty, B. \& A. Sesia Jr., (2005). An Overview of Project Finance - 2004 Update, Harvard Business School Case \#205-065.

Esty, B. \& A. Sesia Jr., (2005). An Overview of Project Finance - 2004 Update, HarvardBusiness School Case \#205-065.

Esty, B., (2003). Why Study Large Projects? Harvard Business School. Case \#203-031.

Fight, A. (2006). Introduction to Project Finance. Essential Capital Markets. Elsvier 1st Edition.

Fight, A. (2006). Introduction to Project Finance. Essential Capital Markets. Elsvier 1st Edition.

Frank Wood, Alan Sangstar (2009). Business Accounting. 12th Edition. Prentice Hall.

Hoffman, S. L., (2001). The Law and Business of International Project Finance, 2nd Ed., New York, Transnational Publishers, Inc. \& The Hague, The Netherlands, Kluwer Law International.

International Accounting Standard. Available at: 27/01/2012http://www.iasplus.com/ standard /ias07.htm

Jennings A.R. (2001). Financial Accounting. 2nd Edition. Continum, New York.

Mawutor, J.K.M. (2014). Analysis of Basel III and risk analysis of management in banking. European Journal of Business and Management, 2014: 161-167.

Mawutor, J.K.M. (2014). Restructuring projects in financial distress. International Journal of Education and Research.

Mawutor, J.K.M. (2014). Role of project finance in emerging economies. Journal of Economics and Sustainable Development,: 145-153.

Mawutor, J.K.M. (2014). The complicity of auditors in financial statement fraud in corporate governance. International Journal of Education and Research.

Mawutor, J.K.M. (2014). The failure of Lehman Brothers: causes, preventive measures and recommendations. Research Journal of Finance and Accounting, 2014: 85-91.

Myers, S. C. \& N. S. Majluf, (1984). Corporate Financing and Investment Decisions when Firms have Information that Investors do not have, Journal of Financial Economics 13, pp. 187-221. http://dx.doi.org/10.1016/0304-405X(84)90023-0

Pandey, I., (2005). Financial Management, 9th Ed., New Delhi, India, Vikas Publishing House Pvt. Ltd.

Parrino, R., A. M. Poteshman \& M. S. Weisbach, (2005). Measuring Investment Distortions when Risk-Averse Managers Decide Whether to Undertake Risky Projects, Financial Management 34, Spring, pp. $21-60$. http://dx.doi.org/10.1111/j.1755-053X.2005.tb00091.x

Worenklein J.J. (2003). The Global Crisis in Power and Infrastructure: Lessons Learnt and New Directions, the Journal of Structured and Project Finance. Spring, pp 7-11. 